\title{
酸加水分解エキスの変異原性
}

(平成 9 年 8 月 25 日受理)

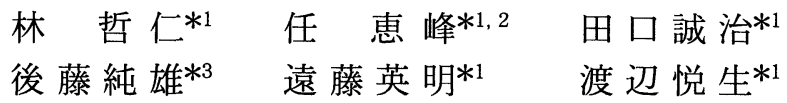

\section{Mutagenicity of Hydrolyzed Proteins}

\author{
Tetsuhito Hayashi*1, Huifeng Ren*1, ${ }^{*}$, Seiji Taguchi*1, Sumio Goto*3, \\ Hideaki ENDO*1 and Etsuo WATANABE*1
}
(*1 Department of Food Science and Technology, Tokyo University of Fisheries: 4-5-7, Konan, Minato-ku, Tokyo 108-8477, Japan; ${ }^{* 2}$ Heilongjiang Commercial College, 50 Tongda Street, Harbin, 150076, People's Republic of China; ${ }^{* 3}$ Department of Community Environmental Science, National Institute of Public Health: 4-6-1, Shirokanedai, Minato-ku, Tokyo 108-8638, Japan)

The presence of 3-chloro-1,2-propanediol (MCP) in hydrolyzed proteins (HPs) was reported, due to the reaction of excessive hydrochloric acid in the system with glycerine derived from neutral fat triglyceride. Since MCP induced immobility of rat sperm and showed mutagenicity against some bacterial test strains, its concentration should be kept as low as possible. Here we report the distribution of MCP in HPs commercially available during 1990-91. The mutagenicity of MCP in these HPs was below the detection limit of the microbiological assay system we employed. Owing to efforts made by manufacturers, no MCP is detectable in HPs currently manufactured in Japan. However, microbiological mutagenic studies indicated that weak, but significant, mutagenicity still exists in some HPs.

(Received August 25, 1997)

Key words: 酸加水分解エキス protein hydrolysate; 3-クロロ-1,2-プロパンジオール 3-chloro1,2-propanediol (MCP); モノクロロヒドリン monochlorohydrin; 变異原性 mutagenicity; 前 進突然变異試験法 forward mutation test

はじめに

酸加水分解エキスは, 原料中のタンパク質を分解し て構成アミノ酸を遊離状とし，それらに含まれる呈味成 分を食品の調味，加工に利用することを目的とした製 品)である. 原料に動物性素材を用いれば hydrolyzed animal protein (HAP), 植物性の場合には hydrolyzed vegetable protein (HVP) と呼ぶが，両者を合わせて

*1 東京水産大学食品生産学科： $\mathbf{T} 108-8477$ 東京都港区港南 4-5-7

*2 黒竜江商学院：中華人民共和国 $\mathbf{T} 150076$ 黒竜江省八ルピ ン市道里区通達街 50

*3 国立公衆衛生院地域環境衛生学部：干108-8638 東京都港 区白金台 4-6-1
HP と略称する.この場合分解条件が適切であれば，夕 ンパク質がすべて遊離のアミノ酸となり，それ以外の反 応は起こらないと思われる。

しかし，実際には素材中のタンパク質量が原料によっ て異なるため, 聞き取り調查によれば各メーカーは, ア ミノ酸回収率を確保する目的で大過剩の酸を投入する傾 向がある. その結果, タンパク質のペプチド結合以外で あ加水分解が起こり, 中性脂質卜リアシルグリセリンで は，グリセリンの水酸基にエステル結合している脂肪酸 を切断する. 生じたグリセリンと遊離脂肪酸のうち, 前 者は3位に塩素イオンが付いたモノクロロヒドリン, 3-chloro-1,2-propanediol (MCP) を生じる2) 4). これが 变異原性を有していたため, 市販 HP 中に分布する 
MCP の濃度を自主的に規制しようとする動きが起きた のは, 1990 年代初頭のことであった. その結果, HAP を製造している各社は製品中の MCP 濃度 1 ppm 未満 を目標値として定め, 製造法の改良に努めた. 分解後の 中和過程で製品の $\mathrm{pH}$ をいったんアルカリ側とする操作 を行うこと ${ }^{5)} よ り$, 問題発生から $1 \sim 2$ 年以内に目標 値の $1 \mathrm{ppm}$ をほぼ達成した. 1990 年当時収集した HP の大部分からは, 目標值をはるかに上回る MCP が検出 されたが，1997 年に入手した大手企業製の HAP では 規制値を越える試料は当然のことながら皆無となり, 懸 命な企業努力の跡が明瞭に示されている. しかし，この ような努力は諸外国では必ずしも実行されていない場合 あ多く, 韓国では 1996 年 $2 \sim 3$ 月にアミノ酸配合醬油 中の MCP の存在が指摘され, 「化学醬油」の不買運動 にまで発展する大きな社会問題6)となった.

著者らは食品の安全性に関する研究の一環として, HAP 製造工程と変異原性の関係について検討した結果, MCP 対策済みとされる市販 HAP の中にも, 依然とし てある強度以上の変異原性を示す製品が多数あることを 見出し, MCP 以外の変異原性が存在することを検討す る必要があると思われた。

そこで本報ではまず第 1 に，1990 年代初頭の市販天 然調味料（熱水抽出エキス, 酸加水分解エキス, 酵素分 解エキス及びそれらの配合調味料） 80 余種における $\mathrm{MCP}$ 濃度の分析結果を報告する. 第 2 に, 微生物試験 による MCP 標準品の単位重量当たりの変異原性の強さ （比活性）を測定したので，その結果を述べる. 第 3 に，1990９1 年当時収集し自主規制值以上の濃度の $\mathrm{MCP}$ が検出された HP 試料のうち, 主要メ一カーの $\mathrm{HAP}$ 製品数種を対象として, 微生物試験法による変異 原性の強さを測定し, それらの変異原性に占める $\mathrm{MCP}$ の寄与の程度を検討したので報告する. 最後に, 現在市 販されている MCP 対策済みの HAP（品名が 90 年当時 と同一の製品, 数検体を含む) における变異原性を微生 物試験によって測定したので, その結果を報告する.

変異原性試験には, 食品のように遊離七スチジンを常 在成分として含む試料の測定にも適している前進突然変 異試験を用い, 変異原性の強さを測定した.

\section{実験方法}

1. 試 料

1) MCP 分析用試料

1990～91 年に入手した市販品で，その内訳は熱水抽 出エキス 36 検体（アサリ, ホ夕テ, ズワイガニ, マイ ワシ, エソ, マグロ, カッオ, かつお節, イカ, ポー ク, ビーフ, チキン, シイタケ, タマネギ), 酸加水分 解エキス (HP) 18 検体 (小麦グルテン, 脱脂加工大豆, コーンミール, 醒油粕, ビール酵母, ポーク, ビーフ, チキン, クジラ), 酵素分解エキス 28 検体 (マイワシ, かつお煮汁, サバ, 廃糖蜜, ビール酵母, ポーク煮汁),
合計 82 検体である. 製品の形状 (ペースト, 液体, 粉 末）に関わらず, 入手後直ちに数本の $100 \mathrm{~mL}$ 容のポ リ容器に小分けし, 密栓して $-30^{\circ} \mathrm{Cで}$ 保存した.

2）微生物試験用試料

（1）MCP 未対策 HAP：冷凍保存した MCP 分析用試 料を使用した。

(2) MCP 対策済 HAP：現在市販されている MCP 対 策済み HP，4社 10 検体を供試した。なお,この うち 2 社 3 検体は, 1990 91 年当時と同一の商品 名で市販されていた.

\section{2. 試料溶液の調製}

1) MCP 分析

試料 $1 \mathrm{~g}$ を蒸留水に溶かし $10 \mathrm{~mL}$ に定容後, その 1 $\mathrm{mL}$ をキストレルートカラム（メルク社, 担体 $1 \mathrm{~g}$ 充 てん）に注入した後, 室温で 10 分間放置した. その後 ジェチルェーテル $25 \mathrm{~mL}$ を数回に分け, このカラムを ゆっくりと自然流下させ, 流出液に無水硫酸ナトリウム $5 \mathrm{~g}$ を加えて脱水後, クデルナダニッシュの装置で濃 縮, 乾固した.これにジェチルエーテル $1 \mathrm{~mL}$ を加えて 溶かし, GC-ECD 分析用試料とした.

2) 微生物試験

(1) 既知変異原性物質：ベンッピレン $(\mathrm{B}[a] \mathrm{P})$, トリ プ-P-2 (Trp-P-2), 2-(2-フリル)-3-(5-ニトロ-2-フリ ル)アクリルアミド (AF-2) 及び MCP の 4 化合物 をまず少量のジメチルスルフォキサイド (DMSO) に溶かし，これを最終的にDMSOを5\%含むよう にろ過滅菌水で希釈した。

(2) HAP 試料: HAP $250 \mathrm{mg}$ を $5 \% \mathrm{DMSO}$ 水溶液 5 $\mathrm{mL}$ に溶かし, メンブランフィルター (Toyo Advantec, $0.45 \mu \mathrm{m})$ でろ過滅菌を行った. これを最 高濃度とし, 万過滅菌済 5\%DMSO 水溶液で 2 倍 希釈を繰り返し, 合計 5 段階濃度の試料液を調製 した.

\section{3. 試薬}

MCP 標準品は東京化成工業の試薬 1 級（純度 98\%） を用いた，変異原性試験に用いた既知変異原性物質，一 般試薬及び培地類は, 特に記したもの以外は和光純薬, 国産化学, 東京化成工業製の生化学用, 精密分析用又は 特級を, DMSO は同仁化学の蛍光試験用を, 調製済補 酵素類はオリエンタル酵母製のコファクターIを用い た. S9 は既報7)のおり Sprague-Dawley 系雄ラット に PCB を投与して誘導し， $9,000 \times \mathrm{g}$ で 20 分間遠沈し て無菌的に調製したものを，使用直前までー $80^{\circ} \mathrm{C}$ に保 存した。

\section{4. 機 器}

$\mathrm{MCP}$ 分析用のガスクロマトグラフには, ${ }^{63} \mathrm{Ni}-\mathrm{ECD}$ 検 出器を装備した島津製作所製の GC-9A を用い, カラム はフューズドシリカキャピラリーカラム (PEG-20M, $0.35 \mathrm{~mm} \times 50 \mathrm{~m})$ を使用した。 
Table 1. 3-Chloro-1,2-propanediol (MCP) Found in Hydrolyzed Proteins Commercially Distributed in Japan in 1990

\begin{tabular}{l|l|l|l|c}
\hline \hline Maker & Raw materials & Munufacturing method & Form & MCP conc. (ppm) \\
\hline A & Wheat gluten & HCI hydrolysis & Liquid & 47.7 \\
B-1-3 & Soy bean* & HCl hydrolysis & Powder (+dextrin) & $53.6^{* *}$ \\
B-4 & Soy bean* & HCl hydrolysis & Liquid & 15.4 \\
C-1 & Yeast & Enzymolysis & Powder (+HAP) & 57.9 \\
C-2 & Yeast & HCl hydrolysis & Powder & 33.2 \\
D-1 & Pork & HCl hydrolysis & Paste (+HVP) & 100.9 \\
D-2-3 & Pork & HCl hydrolysis & Paste (+MSG) & $50.5^{* * *}$ \\
D-4 & Pork & HCl hydrolysis & Powder & 30.1 \\
D-5 & Pork & HCl hydrolysis & Powder (+sugar, $\mathrm{K}_{4} \mathrm{O}_{7} \mathrm{P}_{2}$ ) & 24.6 \\
D-6 & Pork & HCl hydrolysis & Liquid & 20.4 \\
E-1 & Crab & Hot water extraction & Liquid (+HVP, salt) & 15.1 \\
E-2 & Sea scallop & Hot water extraction & Liquid (+HVP, HAP) & 13.1 \\
F-1 & Yeast & Enzymolysis & Powder (+HVP, bonito extract) & 15.0 \\
F-2 & Pork+ Beef & Enzymolysis & Powder (+HAP, bonito extract) & 7.4 \\
G-1 & Beef & HCl hydrolysis & Powder & 21.2 \\
G-2 & Beef & HCl hydrolysis & Liquid & 8.5 \\
H-1 & Whale & HCl hydrolysis & Paste & 88.0
\end{tabular}

* Soy bean, corn meal, and soy sauce residue; ** Average of 3 samples; *** Average of 2 samples

\section{MCP 定量法}

荒木らの方法 ${ }^{8}$ に準じたが，前後のピークとの分離が 不十分であったため, 昇温速度等を次のように改变し た.すなわちキャリアに $\mathrm{N}_{2}$ ガス $(50 \mathrm{~mL} /$ 分，スプ リット比 $1: 90)$, メイクアップガスにも $\mathrm{N}_{2}(60 \mathrm{~mL} /$ 分）を用い, 検出器温度は $260^{\circ} \mathrm{C}$ した. カラムオーブ ンは $70^{\circ} \mathrm{C}$ で 4 分間保持後, 毎分 $4^{\circ} \mathrm{C}$ 昇温し, $210^{\circ} \mathrm{C}$ で 30 分間保持した. 分析には 2.1) で調製した試料 $2 \mu \mathrm{L}$ を注入したが，この条件下では MCP の保持時間は 39.3 分で, 検量線は 0 300 ppm の範囲で直線を示し, 検 出限界は $0.2 \mathrm{ppm}$ であった. 各試料とも標準品添加試 験で MCP であることを確認後, 2 回の分析の平均值を 採用した.

\section{6. 前進突然変異 $(F M)$ 試験法}

エイムス 法 $^{9)}$ は, 試料中に遊離ヒスチジンが混在する 之陰性対照值が高くなり, 正確な試験結果の判定に支障 を来すが, 被検物質の前処理過程で変異原性の一部が失 われることは既に報告7)した。本報で用いた FM 法は共 存する遊離ヒスチジンの影響を受けない(10)ので, 調味料 の分析には適している. 試験菌には，8-アザグアニン (8AG) 抵抗性検出に優れた Salmonella typhimurium TA 1535 に, 変異原性物質検出感度を高める目的で TA 2000 のプラスミド pKM101 を導入したTM677 株 ${ }^{11)}$

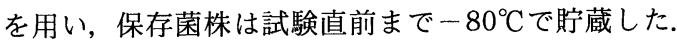
実際の FM 試験に当たっては, TM677 株を試験菌とし て用いる Skopek らの標準 FM 法 ${ }^{11,12)}$ の改良法 ${ }^{13)}$, 更 に縮小しかつ実験系を簡易化した方法 ${ }^{14)}$ を用いた．変異 コロニ一出現数が陰性対照の 2 倍以上の用量域で, か
Table 2. Mutagenicity of Authentic Mutagenic Compounds by forward Mutation Assay Using Salmonella typhimurium TM677 (Mutation frequency*/mg/plate)

\begin{tabular}{ccc}
\hline \hline Compound & $+\mathrm{S} 9$ & $-\mathrm{S} 9$ \\
\hline $\mathrm{MCP}$ & 0.00078 & 0.0055 \\
$\mathrm{~B}[a] \mathrm{P}$ & 1.4688 & $* *$ \\
Trp-P-2 & 4.5169 & $* *$ \\
$\mathrm{AF}-2$ & $* *$ & 194.000 \\
\hline
\end{tabular}

* (Number of colonies of mutants - number of colonies on negative control plate)/number of colonies on plates without $8-\mathrm{AG}$

** Not tested

つ用量曲線が直線性を示している部分の傾きから最小二 乗法を用い, 比活性（プレート1枚当たり, 単位重量 当たりの変異率 $\left.{ }^{14)}\right)$ を算出した.

\section{結果及び考察}

1. 1990〜91 年に市販されていた市販天然エキスに おける MCP の分布

分析に供した熱水抽出エキス, 酵素分解エキス, 酸加 水分解エキス (HP) など合計 82 検体のうち 20 検体から MCP が検出された．MCP が検出されたエキスの製造 原料, 製造方法, 形状及び MCP 濃度は, 一括して Table 1 に示した.これらはいずれもHPそのあの

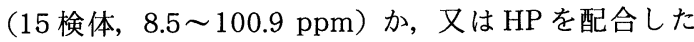
製品（5 検体，7.4〜 57.9 ppm）であった. しかし熱水 抽出エキス（34 検体）及び酵素分解エキス（28 検体） 
Table 3. Concentration of MCP and Mutagenicity of Hydrolyzed Animal Protein Manufactured in $1990 \sim 91$

\begin{tabular}{cclccc}
\hline \hline Sample No. & Materials & Form & MCP conc. & + S9 & - S9 \\
\hline A-1 & Pork & Power & 30.1 & - & + \\
A-2 & Pork & Liquid & 20.4 & - & \pm \\
B-1 & Beef & Powder & 21.2 & \pm & + \\
B-2 & Beef & Liquid & 8.5 & - & + \\
C-1 & Whale & Paste & 88.0 & - & + \\
\hline
\end{tabular}

$+:$ Positive (number of mutants was more than double of spontaneous colonies)

\pm : Pseudo-positive (number of mutants was less than double, but over 1.5 times)

-: Negative (number of mutants was less 1.5 times of spontaneous colonies)

Concentration of MCP was determined by GC-ECD after Araki et al. Mutagenicity was measured by the forward mutation assay using Salmonella typhimurium TM677.

Table 4. Mutagenicity Found Currently Commercially Available Hydrolyzed Animal and Vegetable Proteins (Mutation Frequency* $\times 10^{-5} / \mathrm{g} /$ plate)

\begin{tabular}{cllcr}
\hline \hline Sample & \multicolumn{1}{c}{ Materials } & Form & + S9 & - S9 \\
\hline A-1 - $^{* *}$ & Pork & Powder & - & 24.19 \\
$-2^{* *}$ & Pork & Liquid & - & $\pm * * *$ \\
B-1 ${ }^{* *}$ & Beef & Powder & 6.27 & 7.65 \\
-2 & Beef & Liquid & - & 11.84 \\
C-1 & Gluten & Liquid & - & 11.46 \\
D-1 & Pork & Paste & 5.94 & 8.61 \\
-2 & Chicken + Vegetable extract & Paste & - & $\pm * * *$ \\
-3 & Chicken & Paste & 3.86 & 6.42 \\
-4 & Beef & Paste & 2.88 & 13.47 \\
-5 & Pork + Beef & Paste & - & 10.14 \\
\hline
\end{tabular}

* (Number of colonies of mutants - number of colonies on negative control plate)/number of colonies on plates without 8-AG

** These three samples were sold under the same trade names as that of manufactured in 1990 91 by the companies, however, being treated to remove MCP in the final process.

*** \pm : Pseudo-positive

のみからなる製品では, MCP は全く検出されなかっ た. 検出された HP 製品の原料や形状は様々であるが, いずれあ塩酸を用いた加水分解法で作られていることが 共通している．MCP 濃度は一般に液体製品よりもぺー ストあるいは粉末製品で高い傾向が見られた．粉末 HP の大半は液体 HP の水分をスプレードライ法で除去して 製造されるので, 製品の単位重量当たりの変異原性は液 体製品より高くなると思われる. 塩酸加水分解製品の中 には MCP が検出限界以下の製品むあったが，この原因 は前駆体である中性脂質の含量が低かったため, 又は添 加した塩酸量がタンパク質の分解でほぼ消費される量で あったためと推察される。

\section{2. 市販 HP (1990 年) 中の変異原性に占める $\mathrm{MCP}$ の割合 \\ 1) $\mathrm{MCP}$ 標準品の変異原性}

9 段階の濃度 $[$ 各段階相互間の濃度差は 2 倍, 最高濃 度は+S9; $320(\mu \mathrm{g} /$ plate),$-\mathrm{S} 9 ; 160]$ に調製した MCP
標準品溶液を試料とし，FM 法で測定した結果を Table 2 に示す. この表から $\mathrm{MCP}$ の突然変異誘発率の比活性 は+S9 条件下では $7.8 \times 10^{-4}$ と, $-\mathrm{S} 9$ 条件下の約 $1 /$ $10\left(5.5 \times 10^{-3}\right)$ であった．この+S9 の結果を間接変異原 性物質である $\mathrm{B}[a] \mathrm{P}$ や Trp-P-2 と, またーS9 条件下で の值を直接変異原性物質である AF-2 のそれと比べる, いずれあおよそ数万分の一程度の強さであった．以上の ことから $\mathrm{MCP}$ は直接変異原性を示すが, 代謝されると $\mathrm{MCP}$ 自身よりやや弱い間接变異原性を持つことを示し ている. また仮に製品中の MCP 濃度が暫定的自主規制 值を超えてむ, 深刻な問題を引き起こす可能性はそれほ ど大きくないと思われる.

2) 1990 年当時の市販 HAP 中の変異原性に占める MCP の割合

$\mathrm{GC}$ の結果, $\mathrm{HAP}$ エキス中には最高で $101 \mathrm{ppm} の$ MCP が含まれることが分かった．今回 FM 法で用いた プレート 1 枚当たりで供試される HP の最高濃度は 
$625 \mu \mathrm{g} /$ plate であるから，したがって，この中に含ま れる MCP 量は最高であ $625 \times 101 \times 10^{-6} \mu \mathrm{g} /$ plate と なり，FM法における MCP の検出限界 $15 \mathrm{mg} /$ plate をはるかに下回るため，むし変異原性がすべて MCP に よるあのであると仮定すれば，これらの結果は陰性しか 示さない岋ずである。しかし実際に，MCP対策がとら れていなかった 90〜91 年当時の製品数検体を FM 試験 にかけたところ, Table 3 に示したように MCP の含有 量とは関係なく, +S9 条件下では 1 検体のみが弱い変 異原性を示したが，－S9 条件下では 5 検体のすべてが 陽性（1検体は擬陽性）であった.この結果から，市販 $\mathrm{HAP}$ の示す変異原性の大半は, MCP 以外の変異原性 物質によるあのと判断された.

\section{MCP 対策済 HAP の変異原性}

そこで次に 1996〜97 年に大手数社が製造した， $\mathrm{MCP}$ 対策済みとされる $\mathrm{HAP}$ 計 10 種を収集し, 変異原 性分布の実態をFM試験法により測定した結果を Table 4 に示した. この表に示したとおり 10 検体のう ち, 間接変異原性 (+S9 条件下) は 4 検体から 2.9 $6.3 / \mathrm{g} /$ plate の変異原性が検出されたのみであったが, 直接変異原性 ( $-\mathrm{S} 9$ 条件下) は $6.4 \sim 24.2 \times 10^{-5} / \mathrm{g} /$ plate の変異原性が 8 検体から検出され, 残る 2 検体は 擬陽性であった，供試した検体がそれほど多くないた め, 原料や製品の形状などと変異原性の多寡との相関性 は見出すことができなかった.

MCP はげっし類の精子運動性に影響を及ぼすなどの National Institute for Occupational Safety and Health (NIOSH) における動物実験結果 ${ }^{15), 16)}$ から, 数年 前に HP 業界でもその生成抑制が深刻な問題となった が, 変異原性そのものはそれほど強くないことを, 公定 法のエイムス試験法 ${ }^{17)}$ のならず, FM 法であ確かめる ことができた. また改良型 HP の微生物試験結果から, 多くのエキス製造会社で実施された酸分解エキス改良法 は, 中和過程におけるアルカリ処理のため MCP は存在 しないが，高濃度の酸を用いて高温/高圧下などの厳し い環境条件下で処理するため, MCP 以外の変異原性物 質が依然として生成していることが明らかになった。こ のことから, 今後, 酸加水分解エキス中に含まれている これら MCP 以外の変異原性物質の化学構造の決定, 分 解条件との関連の解明などを追究するとともに，それら が生成しにくい, あしくは一度生成しても確実に除去又 は破壊できるような, 安全な HP 製造条件の確立が急務 であると思われる。

謝辞

本研究は日本学術振興会外国人特別研究員任 恵峰
と，その受け入れ研究者である林 哲仁が中心になって 行ったもので, 費用の一部は文部省科学研究費によりま した. 此処に記して深謝します。

文献

1) 越智宏倫：“天然調味料の原料「天然調味料」”p. $40 \sim 42$ (1993) 光琳, 東京.

2) Velisek, J., Davidek, J., Hajslova, J., Kubelka, V., Janicek, G., Monkova, B.: Z. Lebensm. Unters. Forsch. 167, $241 \sim 244$ (1978)

3) Silhankova, L., Smid, F., Cerna, M., Davidek, J., Velisek, J.: Mutation Res. 103, 77 81 (1992).

4) Velisek, J., Davidek, J., Kubelka, V., Janicek, G., Svobodoba, Z., Simicova, Z.: J. Agric. Food Chem. 28, 1,142 $\sim 1,144$ (1980).

5）犬飼太彦：“タンパク加水分解物の製造方法” 日本国公開 特許公報. 平 4-88951, p. 315 321 (1992).

6) 落合慶一郎, 林 哲仁, 李 秉武, 劉 永濟：経実連七 ミナ「化学醬油の危険性」講演・討論記録, 経済正義 30 号, p. 214 233 (1996).（原典は韓国語）

7) 任 恵峰, 林 哲仁, 大久保忠利, 後藤純雄, 渡辺悦生: 日水誌. 63, 90〜96 (1997).

8）荒木恵一, 新家淳治, 早川修二, 金丸 豪: 三重県環境 科学センタ一研究報告 8, 123 125 (1988).

9）労働省安全衛生部化学物質調查課：“安衛法における変異 原性試験一テストガイドラインと GLP”第 1 版, p. 29 ６3 (1991) 中央労働災害防止協会, 東京.

10) Hayashi, T., Ren, H., Goto, S., Endo, H., Watanabe, E.: J. Sci. Food Agric. 70, 16 24 (1996).

11) Skopek, T., Liber, H. L., Krolewski, J. J., Thilly, W. G.: Proc. Natl. Acad. Sci. USA, 75, 410 414 (1978).

12) Skopek, T., Liber, H. L., Kaden, D. A., Thilly, W. G.: Proc. Natl. Acad. Sci. USA, 75, 4,465 4,469 (1978).

13) 高木敬彦, 後藤純雄, 村田元秀, 松下秀鶴, Lewtas, J.: 大気污染学会誌 23, 9 19 (1988).

14) 任 恵峰, 林 哲仁, 後藤純雄, 遠藤英明, 渡辺悦生: 食衛誌. 37, 301 307 (1996).

15) National Institute for Occupational Safety and Health: Health hazard data on 3-chloro1,2-propanediol (RTECS number; TY4025000), Data of last updated, 91/07.

16) WHO Technical Report Series 837: Evaluation of certain food additives and contaminats, 3-chloro-1,2propanediol and 1,3-dichloro-2-propanol, p. 31 32 (1993).

17) 大久保忠利, 林 哲仁, 渡辺悦生, 遠藤英明, 後藤純雄, 遠藤 治, 溝口次夫, 森 康明: 日水誌. 61, 596 601 (1995). 